\title{
PENGARUH PERIKLANAN DAN KUALITAS PRODUK TERHADAP KEPUTUSAN MEMBELI HANDPHONE MEREK SAMSUNG PT. TELKOMSEL
}

\author{
Nurdin $^{1)}$, Tjipto Djuhartono ${ }^{2)}$ \\ Program Studi Pendidikan Bahasa dan Sastra Indonesia, Fakultas Bahasa Dan Seni ${ }^{1)}$ \\ Program Studi Pendidikan Ekonomi, Fakultas Ilmu Pendidikan dan Pengetahuan Sosial ${ }^{2)}$ \\ Universitas Indraprasta PGRI Jakarta \\ Email : Dr.Nurdin3067@gmail.com ${ }^{1)}$ \\ Email : tjiptodjuhartono@gmail.com ${ }^{2}$
}

Diterima: Februari; Disetujui: Maret; dipublikasikan: 28 April 2019

\begin{abstract}
This study aims to determine the effect of advertising media and product quality on the decision to buy mobile phones. Research Methods are survey research. The subject of this study as many as 50 people in the housing community di Perumahan Unggul Graha Permai. Data were collected by a questionnaire instrument using Likert. The validity of the data obtained by the validity and reliability test, all data have a normal distribution. The results showed that the advertising media gave a significant influence on the decision to buy a mobile phone. Likewise product quality gives a significant influence on the decision to buy a mobile phone. Coefficient of determination $(R)^{2}$ is advertising media and product quality has a strong relationship to decision to buy handphone.
\end{abstract}

Keywords: Advertising, Product, Purchase

\begin{abstract}
ABSTRAK
Penelitian ini bertujuan untuk mengetahui besarnya pengaruh media periklanan dan kualitas produk terhadap keputusan membeli handphone. Metode Penelitian yang digunakan adalah penelitian survey. Subjek penelitian ini sebanyak 50 orang masyarakat di perumahan Unggul Graha Permai. Data dikumpulkan dengan instrumen angket menggunakan skala likert. Keabsahan data diperoleh dengan uji validitas dan reliabilitas, semua data memiliki distribusi normal. Hasil penelitian menunjukkan bahwa media periklanan memberi pengaruh yang signifikan terhadap keputusan membeli handphone. Begitu juga kualitas produk memberi pengaruh yang signifikan terhadap keputusan membeli handphone. Koefisien determinasi $(\mathrm{R})^{2}$ adalah media periklanan dan kualitas produk mempunyai hubungan yang kuat terhadap keputusan membeli handphone .
\end{abstract}

Kata Kunci: Perikalanan, Produk, Membeli 


\section{PENDAHULUAN}

Dewasa ini, persaingan bisnis sangat ketat. Untuk dapat memenangkan, persaingan yang ketat, produsen harus dengan tepat mengevaluasi dan memilih pasar yang dituju. Periklanan merupakan inti dari setiap produsen dalam usaha untuk memasarkan produk atau jasa kepada konsumen. Perusahaan menyediakan produk yang berkualitas dengan harga yang dapat dijangkau oleh konsumen. Dengan berkembangnya teknologi sekarang ini, masyarakat berusaha menggunakan handphone sebagai alat komunikasi. PT Telkomseladalah perusahaan yang bergerak di bidang jasa informasi berusaha memberi pelayanan yang baik sehingga masyarakat menggunakan jasa telekomunikasi. PT Teklkomsel selalu berusaha untuk memberi pelayanan yang baik kepada konsumen, sehingga konsumen mempunyai minat untuk membeli produk yangtersedia.

Pendapat Kotler dikutip Grace (jurnal manajemen, 2011: 134), menyatakan bahwa tantangan yang dihadapi oleh kebanyakan produsen sekarang ini adalah mengenai cara untuk membangun, mengelola, dan mempertahankan bisnis yang sehat dan kompetitif dalam pasar serta lingkungan yang terus-menerus berubah. Untuk itu, perusahaan berusaha untuk dapat meningkatkan kepuasan konsumen dalam membeli suatu produk. Perusahaan perlu mengomunikasikan produknya kepada konsumen. Dengan melihat banyaknya persaingan dan perilaku konsumen yang begitu beragam, salah satu jalan yang ditempuh untuk menawarkan produknya adalah mengadakan periklanan. Upaya yang dilakukan untuk menarik minat konsumen dalam membeli produk yang ditawarkan perusahaan, yaituperusahaan menyediakan produk yang berkualitas dan mengadakan periklanan.

Menurut Terry (1989:72), keputusan adalah sebagai pemilihan yang didasarkan kriteria tertentu dua atau lebih alternatif yang ada. Menurut Nugroho (2002: 2), keputusan membeli merupakan proses aktivitas masing-masing individu yang dilakukan dalam rangka evaluasi, mendapatkan, penggunaan atau mengatur barang dan jasa. Kotler (1987: 98)), menyatakan bahwa keputusan membeli terjadi karena melalui proses prilaku yang meliputi empat tahap, yaitu (1) pengenalan kebutuhan, artinya proses pembelian diawali dengan adanya kebutuhan yang dirasakan konsumen, (2) pencairan informasi artinya setelah konsumen merasakan adanya kebutuhan sesuatu barang atau jasa. Selanjutnya konsumen mencari informasi baik yang disimpan dalam ingatan (information internal), maupun informasi yang didapat dari lingkungan (eksternal), (3) evaluasi informasi artinya konsumen mengevaluasi alternatif pilihan dalam memenuhi kebutuhannya, dan (4) kepuasan membeli artinya konsumen yang telah melakukan pilihan terhadap berbagai alternatif, biasanya konsumen membeli produk yang paling disukai.

Menurut Soekanto (2005: 173), untuk mengambil keputusan dalam membeli suatu produk, ada beberapa faktor yang mempengaruhi seorang pembeli, yaitu (1) pengaruh sosial artinya para pemasar harus mengerti kultur individu dan nilai-nilai yang terkandung di dalamnya, elemen yang perlu diperhatikan adalah nilai, bahasa, mitos, adat, ritual, dan hukum mempertajam perilaku atas kultur, (2) pengaruh individu artinya konsep diri dan gaya hidup seseorang dengan cara mengumpulkan dan mengelompokkan kekonsistenan reaksi seseorang mengenai situasi yang sedang terjadi, dan (3) pengaruh psikologi artinya suatu pola yang diorganisir melalui pengetahuan dan kemudian dipegang oleh seorang individu sebagai suatu kebenaran dalam hidupnya.

Menurut Liliweri (2008: 38), keputusan membeli didasarkan dua dimensi, yaitu (1) seberapa jauh pembuatan keputusan membeli, dimensi ini menggambarkan rangkaian dari pengambilan keputuan yang bersifat kebiasaan. Konsumen dapat menggabrkan keputusannya pada proses cognitive (berpikir), dari pencaian inormasi dan evaluasi alternatif merek. Artinya konsumen melakukan pembelian pada satu merek saja atau selalu terjadi pembelian yang konsisten, dan (2) derajat keterlibatan pembelian, dimensi ini menggambarkan keterlibatan konsumen akan mengalami beberapa resiko seperti financial risk yaitu produk yang penting 
dalam kelompoknya atau psychological risk yaitu pengambilan keputusan yang salah akan mengakibatkan fatal. Pendapat Anoraga dikutip Grace Christianti Wibowo (jurnal manajemen, 2011: 134), menyatakan bahwa niat membeli merupakan suatu proses pengambilan keputusan yang dilakukan oleh konsumen sebelum mengadakan pembelian atas produk yang ditawarkan atau yang dibutuhkan oleh konsumen tersebut.

Menurut Efendi (2000: 45), media adalah segala sesuatu yang dapat dijadikan sebagai alat perantara untuk mencapai tujuan tertentu. Swasta (2001: 72), menyatakan bahwa media periklanan adalah lembaga yang mempunyai kegiatan usaha menciptakan dan menyelengarakan media (alat komunikasi), yang ditujukan kepada masyarakaat umum. Kotler (2001: 87), menyatakan bahwa langkah utama dalam menyeleksi media adalah : (1) menentukan jangkauan, frekuensi, dan dampaknya, (2) memilih tripe media utama, (3) menyeleksi wahana media, dan (4) menetukan waktu penayangan. Dari hal tersebut dapat dinyatakan bahwa perencanaan media harus diketahui daya jangkauan frekwensi dan dampak dari setiap tipe media utama. Tipe media utama itu terdiri dari surat kabar, televisi, kantor pos, radio, majalah, dan internet, dan menjadwalkan iklan selama periode tertentu.

Menurut Klipper dalam Liliweri (2008: 47), istilah iklan berasal dari bahasa latin, yaitu ad-vere yang berarti mentransfer pikiran dan gagasan kepada pihak lain. Selanjutnya dikatakan bahwa iklan merupakan proses komunikasi yang mempunyai kekuatan yang sangat penting sebagai alat pemasaran untuk membantu menjual barang, memberi pelayanan serta gagasan atau ide-ide melalui saluran tertentu dalam bentuk informasi persuasif. Menurut Alwi (2002: 98), iklan adalah berisi pesanan untuk mendorong, membujuk khalayak ramai agar tertarik pada barang atau jasa yang ditawarkan. Menurut Jain (2001: 149), periklanan adalah suatu program untuk mempersiapkan berita tentang produk dan menyebarluaskan kepada khalayak ramai. Foster (2003: 107), menyatakan bahwa periklanan, yaitu suatu kegiatan yang mempergunakan atau menyewa tempat pada suatu media komunikasi, seperti surat kabar, majalah, televisi, dan radio untuk memperkenalkan hasil produksi barang dan jasa yang baru dari suatu perusahaan. Menurut Swasta (2000: 98), periklanan adalah komunikasi nonindividu dengan sejumlah biaya melalui berbagai media yang menurut Kasali (1996:89), iklan berarti pesan yang menawarkan suatu produk yang ditujukan kepada masyarakat melaui suatu media.

Pujiyanto (2001: 3-4), menyatakan bahwa iklan merupakan sarana komunikasi mengenai produk yang disampaikan berbagai media dengan baik pemrakarsa agar masyarakat tertarik untuk menyetujui dan mengikuti. Selanjutnya dijelaskan bahwa iklan merupakan media informasi yangdibuat sedemikian rupa agar dapat menarik minat khalayak, serta memiliki karakteristik tertentu dan persuasif sehingga para konsumen khalayak secara sukarela terdorong untuk melakukan sesuatu tindakan sesuai dengan yang diinginkan pengiklan.Menurut Tom (2004:55), iklan mempunyai kekuatan dan kelemahan, kekuatan iklan, yaitu (1) dapat memberi beraneka ragam kreativitas yang dapat diimplementasikan melalui penglihatan dan suara, (b) mampu mengatasi pesan dan posisi paling kompleks, misalnya, gaya hidup masyarakat perkotaan dan pedesaan, (3) iklan dibayar untuk publisitas artinya perusahaan dapat memilih media yang tepat untuk mempunyai sasaran, melaksanakan kampanye, tetapi pesan iklan harus legal, sopan, jujur, dan benar, dan (4) dalam pemasaran langsung, iklan mampu berperan sebagai tenaga penjualan, sedangkan dalam lingkup yang luas iklan bisa membantu mendekatkan pada penjualan, biasanya dengan cara membangun merek.

Menurut Joewano (2003: 126), kualitas adalah sebagai tingkat keberhasilan di dalam melaksanakan tugas serta kemampuan untuk mencapai suatu tujuan yang ditetapkan. Suatu pekerjaan dikatakan baik dan sukses jika tujuan yang diinginkan dapat dicapai dengan baik. Selanjutnya, dikatakan ada empat hal yang perlu diperhatikan untuk memahami pekerjaan seseorang, (a) sampai sejauh mana tujuan dan target kerja yang ditetapkan berhasil dicapai seseorang, (2) sampai sejauh mana tujuan dan target tersebut sesuai standar dan kualitas yang tetapkan, (3) kesulitan-kesulitan apa saja yang ditemui karyawan dan bagaimna mereka 
mengatasinya, dan (4) bagaimana profil prestasi karyawan. Kemampuan dan keterampilan mempunyai peranan yang erat terhadap pekerjaan, di samping itu, personaliti seperti konsep diri motivasi, dan sikap. Kemampuan dan keterampilan merupakan suatu persyaratan bagi keberhasilan dalam suatu proses perwujudan kerja. Menurut Wyckof dalam Lovelok (1988: 12), kualitas adalah tingkat keunggulan yang diharapkan dan pengendalian atas tingkat keunggulan untuk memenuhi keinginan pelanggan. Gronros (1999: 12), menyatakan bahwa kualitas terdiri atas tiga komponen utama, yaitu (a), technical quality yang berkaitan dengan kualitas output yang dipersiapkan pelanggan, (b) fungtional quality yang berkaitan dengan kualitas cara penyampaian jasa, dan (3) corporationimage berupa citra umum, profit, reputasi, dan daya tarik pelnggan. Menurut Wolker ( 1995: 2), menyatakan bahwa suatu produk dikatakan bermutu apabila produk dapat memenuhi kebutuhan konsumen.

Menurut Lamb (2001: 214), produk adalah segala sesuatu, baik menguntungkan maupun tidak yang diperoleh seseorang melalui pertukaran. Selanjutnya dikatakan bahwa produk merupakan segala sesuatu yang dapat ditawarkan produsen dapat diklasifikasikan ke dalam tiga kelompok, yaitu: (a) barang tidak tahan lama (non durable gmoods), yaitu barang berwujud yang biasanya habis dikomsusi dalam satu atau beberapa kali pemakaian, (b) barang tahan lama (durable goods), yaitu barang berwujud yang biasanya bertahan lama dengan banyak pemakaian, dan (c) jasa (ice), ), yaitu merupakan aktivitas, mamfaat atau kepuasan yang ditawarkan untuk dijual. Selanjutnya dikatakan ada tiga elemen utama yang terdapat di dalam produk (bauran produk), yang dipandang penting oleh konsumen dan dijadikan dasar pengambilan keputusan pembelian, yaitu (a) merek merupakan nama, istilah, tanda atau simbol, disain, warna atau kombinasi atribut produk lainnya yang diharapkan dapat memberikan identitas dan differensial terhadap produk pesaing, (b) kemasan merupakan proses berkaitan dengan perencanaan dan pembuatan wadah atau pembungkus untuk suatu produk. Pemberian kemasan dalam suatu produk bisa memberikan tiga mamfaat utama, yaitu : mamfaat komunikasi, fungsional, dan perseptual, dan (c) jaminan adalah janji yang merupakan kewajiban produsen atas produknya kepada konsumen. Jaminan dapat meliputi kualitas produk dan pelayanan.

Menurut Kotler (2001: 6), produk adalah segala yang dapat diberikan kepada konsumen guna memuaskan suatu kebutuhan atau keinginan, sedangkan Laksana (2008: 67), produk, yaitu segala sesuatu baik yang bersifat fisik maupun nonfisik yang dapat ditawarkan kepada konsumen untuk memenuhi keinginan dan kebutuhannya. Selanjutnya dikatakan untuk dapat meningkatkan penjualan atau menarik minat pembeli., perusahaan perlu memperbaiki kualitas produknya berupa (a)new product line artinya produk baru yang memungkinkan perusahaan memasuki pasar yang telah mapan, (b) additions in exixting product line artinya produk yang baru yang dilengkapi suatu line produk perusahaan yang tidak mantap (ukuran, kemasan, dan model), (c) improvements and revisions of exiting product artinya produk baru yang memberikan kinerja yang lebih baik dan menggantikan produk yang telah ada, (d) repositioneringartinya produk yang telah ada diarahkan kepada segmen atau pasar baru, dan (e) cost reductions artinya produk baru yang menyediakan kinerja serupa dengan harga yang lebih murah.

\section{METODE}

Penelitian ini merupakan penelitian survei. Variabel terikatnya keputusan membeli handphone, variabel bebas media periklanan dan kualitas produk. Penelitian dilaksanakan di Bekasi pada bulan Januari tahun 2018. Populasi penelitian masyarakat di perumahan Unggul Graha Permai, subjek penelitian sebayak 50 orang yang diambil secara acak, pengumpulan data menggunakan skala likert. Keabsahan data diperoleh dengan uji validitas dan uji reliabilitas. 
Berdasarkan hasil uji normalitas pada tingk $\alpha 0.05$ subjek penelitian memiliki distribusi normal. Data dianalisis dengan menggunakan SPSS.

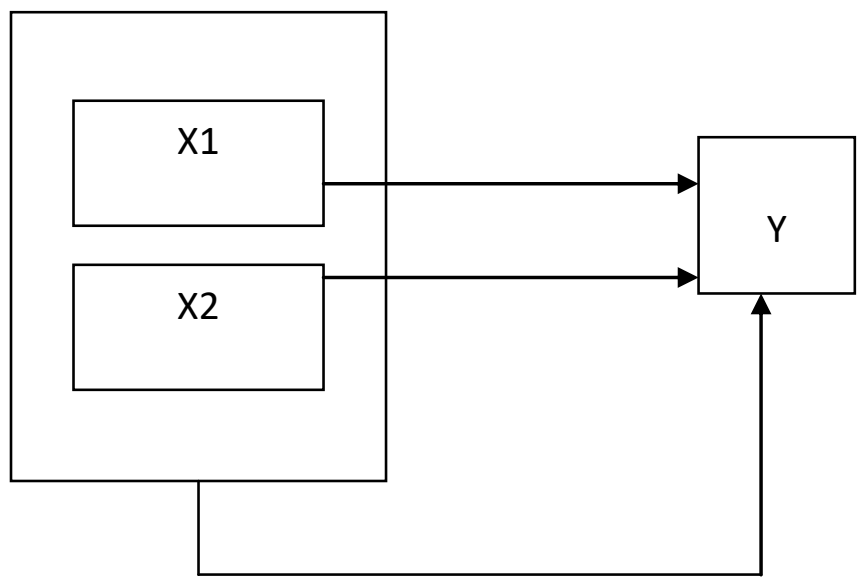

Gambar. Konstalasi penelitian

Keterangan :

$\mathrm{Y}=$ Keputusan membeli handphone

$\mathrm{X} 1=$ Media periklanan

$\mathrm{X} 2=$ Kualitas produk

\section{HASIL DAN PEMBAHASAN}

Selanjutnya dalam menguji penelitian ini,tahapannya adalah melakukan uji Linearity terhadap variabel yang ada. Adapun hasilnya adalah sebagai berikut:

Tabel.1

Uji Linearity Persamaan RegresiMedia Periklanan Terhadap

Keputusan MembeliHanphone

\begin{tabular}{|c|c|c|c|c|c|c|c|}
\hline \multicolumn{8}{|c|}{ ANOVA Table } \\
\hline & & & $\begin{array}{l}\text { Sum of } \\
\text { Squares }\end{array}$ & Df & $\begin{array}{l}\text { Mean } \\
\text { Square }\end{array}$ & $\mathrm{F}$ & Sig. \\
\hline \multirow{5}{*}{$\begin{array}{l}\text { Membeli * } \\
\text { Periklanan }\end{array}$} & \multirow{3}{*}{$\begin{array}{l}\text { Between } \\
\text { Groups }\end{array}$} & (Combined) & 3543.764 & 3 & 209.432 & 3.873 & .000 \\
\hline & & Linearity & 4529.086 & 1 & 4529.086 & 74.751 & .000 \\
\hline & & $\begin{array}{l}\text { Deviation from } \\
\text { Linearity }\end{array}$ & 712.552 & 30 & 53.908 & .807 & .751 \\
\hline & \multicolumn{2}{|c|}{ Within Groups } & 6074.092 & 218 & 27.954 & & \\
\hline & \multicolumn{2}{|l|}{ Total } & 7654.912 & 298 & & & \\
\hline
\end{tabular}

Kriteria pengujian nilai sig $0,751>0,05$ berarti persamaanregresimedia periklanan terhadap keputusan membeli handphoneadalah linier 
Tabel .2

Uji Linearity PersamaanRegresiKualitas Produk Terhadap Keputusan Membeli Handphone

ANOVA Table

\begin{tabular}{|c|c|c|c|c|c|c|c|}
\hline & & & $\begin{array}{l}\text { Sum of } \\
\text { Squares }\end{array}$ & Df & $\begin{array}{l}\text { Mean } \\
\text { Square }\end{array}$ & $\mathrm{F}$ & Sig. \\
\hline \multirow{5}{*}{$\begin{array}{l}\text { Membeli * } \\
\text { Produk }\end{array}$} & \multirow{3}{*}{$\begin{array}{l}\text { Between } \\
\text { Groups }\end{array}$} & (Combined) & 2341.098 & 28 & 206.095 & 2.431 & .000 \\
\hline & & Linearity & 3984.158 & 1 & 3984.158 & 35.095 & .000 \\
\hline & & $\begin{array}{l}\text { Deviation from } \\
\text { Linearity }\end{array}$ & 2097.223 & 27 & 27.453 & .714 & .703 \\
\hline & \multicolumn{2}{|c|}{ Within Groups } & 3087.095 & 270 & 38.902 & & \\
\hline & \multicolumn{2}{|l|}{ Total } & 7017.994 & 298 & & & \\
\hline
\end{tabular}

Kriteria pengujian nilaisigma sebesar $0,703>0,05$ berarti persamaanregresikualitas produk terhadap keputusan membeli handphone adalah linier.

Tabel.3

Uji-T

\begin{tabular}{|c|c|c|c|c|c|c|}
\hline \multicolumn{7}{|c|}{ Coefficients $^{\mathrm{a}}$} \\
\hline \multirow[b]{2}{*}{ Model } & $\begin{array}{c}\text { Unstandardized } \\
\text { Coefficie }\end{array}$ & $\begin{array}{c}\text { Standardized } \\
\text { Coefficie }\end{array}$ & & & & \\
\hline & & $\mathrm{B}$ & Str.Error & Beta & $T$ & Sig \\
\hline \multirow[t]{3}{*}{1} & (Constant) & 631 & .527 & & 3.982 & .000 \\
\hline & Periklanan & .320 & .372 & .318 & 3.885 & .000 \\
\hline & Kualitas produk & .398 & .341 & .420 & 4.012 & .001 \\
\hline
\end{tabular}

Media Periklanan berpengruh secera signifikan terhadap keputusan membeli handphone Kriteria pengujian: Nilai $\mathrm{t}_{\text {hitung }}=3,885>\mathrm{t}_{\text {tabe }}=2.374$ dan nilai $\operatorname{sig}=0.000<0.05$.

Kualitas produk berpengaruh secara signifikan terhadap keputusan membeli handphone Kriteria pengujian : Nilai $\mathrm{t}_{\text {hitung }}=4,012>\mathrm{t}_{\text {tabel }}=2,374$ dan nilai sig $=0.001<0.05$.

Tabel.4

Uji F

ANOVA $^{\mathrm{a}}$

\begin{tabular}{llrrrrr}
\hline Model & & Sum of Squares & df & Mean Square & F & \multicolumn{1}{c}{ Sig. } \\
\hline \multirow{3}{*}{1} & Regression & 3,095 & 3 & 1,003 & 43,761 & $.000^{\mathrm{a}}$ \\
\cline { 2 - 7 } & Residual & 3,732 & 39 & 072 & & \\
\cline { 2 - 7 } & Total & 4,174 & 37 & & & \\
\hline
\end{tabular}

a. Predictors: (Constant): Media periklanan, kualitas produk

b. Dependent Variable: Keputusan membeli

Media periklanan dan kualitas produk secara bersama-sama memberi pengaruh yang signifikan terhadap keputusan membeli handphone.

Kriteria pengujian: NilaituF $F_{\text {hitung }}=43,761>\mathrm{F}_{\text {tabe }}=2,374$ dan nilai $\operatorname{sig}=0.000<0.05$. 
Tabel. 5

Koefisien determinasi

\begin{tabular}{|c|c|c|c|c|c|}
\hline \multicolumn{6}{|c|}{ Model Summary } \\
\hline Model & $\mathrm{R}$ & R Square & Adjusted R Square & $\begin{array}{c}\text { Std. Error of the } \\
\text { Estimate }\end{array}$ & $\begin{array}{l}\text { Durbin- } \\
\text { Watson }\end{array}$ \\
\hline 1 & $.903^{\mathrm{a}}$ & .813 & 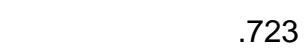 &, 5021 & 2,519 \\
\hline
\end{tabular}

Nilai koefisien determinasi $(\mathrm{R})^{2}$ sebesar $81.3 \%$ media periklanan dan kualitas produk mempunyai hubungan yang sangat kuat terhadap keputusan membeli handphone, sedangkan sisanya $18,7 \%(100 \%-81,3 \%)$ tidak dianalisis dalam penelitian ini.

Sesuai dengan hasil penelitian yang mengacu pada pandangan Efendi (2000: 45), menyatakan bahwa media merupakan suatu sarana yang dapat dijadikan sebagai alat untuk mencapai tujuan tertentu. Pandangan Swasta (2001: 72), menyatakan bahwa media periklanan adalah lembaga yang mempunyai kegiatan usaha untuk menciptakan dan menyelengarakan media (alat komunikasi), yang ditujukan kepada masyarakat umum. Media periklanan yang baik dapat meningkatkan keinginan konsumen memili suatu produk. Mengacu pandangan Nugroho (2002: 2), keputusan membeli merupakan proses aktivitas masing-masing individu yang dilakukan dalam rangka evaluasi, mendapatkan, menggunakan atau mengatur barang dan jasa. Mengacu pandangan Soekanto (2005: 173), untuk mengambil keputusan dalam membeli suatu produk, faktor yang mempengaruhi seorang pembeli, yaitu pengaruh sosial artinya para pemasar harus mengerti kultur individu dan nilai-nilai yang terkandung di dalamnya, yang perlu diperhatikan adalah nilai suatu produk. Perusahaan selalu berusaha memperbaiki media periklanan supaya konsumen mempunyai minat mengadakan pembelian terhadap produk yang disiapkan.

Sesuai dengan hasil penelitian dan mengacu pandangan Joewano (2003: 126), kualitas merupakan suatu kemampuan untuk mencapai suatu tujuan yang ditetapkan.Menurut Lamb (2001: 214), produk adalah segala sesuatu, baik menguntungkan maupun tidak yang diperoleh seseorang melalui pertukaran. Selanjutnya dikatakan bahwa produk merupakan segala sesuatu yang dapat ditawarkan produsen Mengacu pandangan Wolker ( 1995: 2), menyatakan bahwa suatu produk dikatakan bermutu apabila produk dapat memenuhi kebutuhan konsumen.

Perusahaan sebaiknya selalu menyiapkan produk-produk yang berkualitas. Mengacu kembali pendapat Soekanto (2005: 173), untuk mengambil keputusan dalam membeli suatu produk dapat dipengaruhi oleh individu artinya konsep diri dan gaya hidup seseorang dalam memenuhi kebutuhan hidupnya.Pendapat Anoraga dikutip Grace Christianti Wibowo (jurnal manajemen, 2011: 134), menyatakan bahwa niat membeli merupakan suatu proses pengambilan keputusan yang dilakukan oleh konsumen sebelum mengadakan pembelian atas produk yang ditawarkan atau yang dibutuhkan oleh konsumen tersebut. Perusahaan berusaha menyediakan produk yang berkualits sehingga konsumenberusaha mengadakan pembelian.

Sesuai hasil penelitian dengan mengacu pendangan Swasta (2001: 72), menyatakan bahwa media periklanan adalah perusahaan yang mempunyai kegiatan usaha menciptakan dan menyelengarakan media (alat komunikasi), yang ditujukan kepada masyarakaat umum. Mengacu pandangan Kotler (2001: 87), menyatakan bahwa langka dalam menyeleksi media adalah menentukan jangkauan, frekwensi, dampaknya, dan penayangan. Dengan adanya media periklanan, perusahaan berusaha menawarkan produknya.

Dengan mengacu pendangan Wyckof dalam Lovelok (1988: 12), menyatnakan bahwa kualitas adalah tingkat keunggulan yang diharapkan dan pengendalian atas tingkat keunggulan untuk memenuhi keinginan pelanggan. Mengacu pandangan Wolker ( 1995: 2), menyatakan bahwa suatu produk dikatakan bermutu apabila produk dapat memenuhi kebutuhan konsumen. 
Jika produk berkualitas, menurut pandangan Anoraga dikutip Grace Christianti Wibowo ( 2011: 134), menyatakan bahwa niat membeli merupakan suatu proses pengambilan keputusan yang dilakukan oleh konsumen sebelum mengadakan pembelian atas produk yang ditawarkan atau yang dibutuhkan oleh konsumen tersebut. Perusahaan selalu berusaha untuk memperbaika media periklanan dan menawarkan produk yang berkualitas sehingga konsumen membeli produk.

\section{SIMPULAN DAN SARAN}

Simpulan

Berdasarkan hasil perhitungan dan analisa, maka dapat diambil simpulan:

1. Hasil pengolahan data diperoleh nilai $\mathrm{t}_{\text {hitung }}=3,885>\mathrm{t}_{\text {tabel }}$ pada $\alpha 5 \%=2,374$, artinya media periklanan berpengaruh signifikan terhadap keputusan membeli handphone.

2. Hasil pengolahan data diperoleh nilai $t_{\text {hitung }}=4,012>$ nilai $t_{\text {table }}$ pada $\alpha 5 \%=2,374$ artinya kualitas produk berpengaruh signifikan terhadap keputusan membeli handphone.

3. Hasil pengolahan data diperoleh nilai koefisien determinasi $(\mathrm{R})^{2}$ sebesar $81,3 \%$, artinya media periklanan dan kualitas produk mempunyai hubungan yang kuat terhadap keputusan membeli handphone.

Saran

1. Perusahaan perlu memperbaiki media periklanan sehingga konsumen mengenal produk yang ditawarkan.

2. Perusahaan sebaiknya menyiapkan produk yang berkualitas dan disesuaiakan dengan harga jualnya.

3. Perushaan perlu menetapkan harga yang normal supaya konsumen membeli Produkyang ditawarkan.

\section{DAFTAR RUJUKAN}

Alwi, H. (2002). Kamus besar Bahasa Indonesia. Departeman Pendidikan Dan Kebudayaan. Jakarta: Balai Pustaka.

Efendi, O.U. (2000). Dinamika Komunikasi. Bandung: Remadja Rosdakarya.

Foster, D.W. (2003). Perinsip-Prinsip Pemasaran. Jakarta:Erlangga.

Gronroos, C.(1999). Sevice Manaement and Markting. Lexington: Mass Book

Grace, C.W. (2011). Jurnal Manajemen. Jakarta: Universitas Tarumanegara. Volume xv/02/Juni/2011.ISSN:1410-3583.

Joewono, H.(2003). Jangan Sekedar Servis. Jakarta: Intisari.

Jain, S.(2001). Manajemen Pemasaran International. Jakarta: Erlangga.

Kotler, P.(1989). Manajemen Pemasaran. Jakarta: Prenhallindo.

Kasali, R. (1996). Membidik Pemasaran Indonesia, Segmentasi Targeting, Positioning. Jakarta: Pustaka Utama.

Liliweri, A.(2008). Dasar-Dasar Komunikasi Periklanan. Jakarta: Citra Aditya Bakti

Laksana, F.(2008). Manajemen Pemasaran. Yogyakarta: Graha Ilmu.

Lamb, Jr.C. (2001). Marketing Management. Jakarta: Salemba Empat.

Nugroho, A. (2002). Perilaku Konsumen. Jakarta: Studio Press.

Pujiyanto, (2001). Periklanan. Malang: Universitas Negeri Malang.

Swasta, B. (2001). Manajemen Pemasaran Modrn. Yogyakarta: Liberty.

Soekanto, S.(2005). Sosiologi Suatu Pengantar. Jakarta: Raja Grafindo Persada. 
Tom, B.(2004). Marketing Communication. Jakarta: Lembaga Manajemen PPM.

Wyckof dalam Lovelock. (1988). Principle of Service Marketing and Management. Prentice Hall: Person Education International, Inc

Wolker, R.(1995). Perilaku Konsumen. Yogyakarta: Andi. 